University of Nebraska - Lincoln

DigitalCommons@University of Nebraska - Lincoln

Inter-relationships of cotton plant height, canopy width, ground coverand plant nitrogen status indicators

\author{
F. M. Muharam \\ Texas Tech University \\ K. F. Bronson \\ USDA-ARS, U.S. Arid-Land Agricultural Research Center, kevin.bronson@ars.usda.gov
}

S. J. Maas

Texas Tech University

G. L. Ritchie

Texas Tech University

Follow this and additional works at: https://digitalcommons.unl.edu/usdaarsfacpub

Muharam, F. M.; Bronson, K. F.; Maas, S. J.; and Ritchie, G. L., "Inter-relationships of cotton plant height, canopy width, ground coverand plant nitrogen status indicators" (2014). Publications from USDA-ARS / UNL Faculty. 1474.

https://digitalcommons.unl.edu/usdaarsfacpub/1474

This Article is brought to you for free and open access by the U.S. Department of Agriculture: Agricultural Research Service, Lincoln, Nebraska at DigitalCommons@University of Nebraska - Lincoln. It has been accepted for inclusion in Publications from USDA-ARS / UNL Faculty by an authorized administrator of DigitalCommons@University of Nebraska - Lincoln. 


\title{
Inter-relationships of cotton plant height, canopy width, ground cover and plant nitrogen status indicators
}

\author{
F.M. Muharam ${ }^{\mathrm{a}}$, K.F. Bronson ${ }^{\mathrm{b}, *}$, S.J. Maas ${ }^{\mathrm{a}}$, G.L. Ritchie ${ }^{\mathrm{a}}$ \\ a Dept. of Plant and Soil Science-MS42122, Texas Tech University, Lubbock, TX 79409, United States \\ b USDA-ARS, U.S. Arid-Land Agricultural Research Center, 21881 N. Cardon Lane, Maricopa, AZ 85138, United States
}

\section{A R T I C L E I N F O}

\section{Article history:}

Received 17 January 2014

Received in revised form

10 September 2014

Accepted 12 September 2014

Keywords:

Proximal sensing

\begin{abstract}
A B S T R A C T
Petiole- $\mathrm{NO}_{3}$, leaf $\mathrm{N}$ and chlorophyll (SPAD) meter readings are good in-season indicators of the $\mathrm{N}$ status of the uppermost part of cotton (Gossypium hirsutum L.) plants. Petiole- $\mathrm{NO}_{3}$, particularly is widely used in the USA as an in-season plant $\mathrm{N}$ test that guides $\mathrm{N}$ fertilizer recommendations in cotton. However, these $\mathrm{N}$ status indicators do not take account of plant biomass, canopy width or percent cover. The objectives of this study were to assess the effect of $\mathrm{N}$ fertilizer rates on the commonly used indicators of plant $\mathrm{N}$ status; leaf $\mathrm{N}$, petiole sap $\mathrm{NO}_{3}$ and chlorophyll meter (SPAD) readings and the plant growth measurements; plant height, canopy width, and percent ground cover, and determine to inter-correlations among the them. Irrigated field studies were conducted at Lubbock, TX USA in 2010 and 2011, New Deal, TX in 2010, and at Halfway, TX in 2011. Zero-N and a full $\mathrm{N}$ fertilizer rate of 134, 101, and $112 \mathrm{~kg} \mathrm{~N} \mathrm{ha}^{-1}$ were used at Lubbock, New Deal, and Halfway, respectively. The 2010 cotton growing season in West Texas was much wetter than average, and the 2011 season was much drier than normal. As a result, plant height, canopy width, and ground cover were greater in the 2010 sites than in 2011. The effects of $\mathrm{N}$ fertilizer were greatest for the two cultivars in subsurface drip irrigation (SDI) at New Deal in 2010 for all three N status indicators, and for the three plant growth measures compared to the other site-years. Correlation analysis indicated that among the three plant $\mathrm{N}$ indicators, leaf $\mathrm{N}$ was the most sensitive to plant parameters. These effects were positive in 2010 and negative in the 2011 dry year. Petiole $\mathrm{NO}_{3}$ was the plant $\mathrm{N}$ indicator that was the most insensitive to plant growth, but the marked seasonal decline pattern reduces its usefulness for late-season $\mathrm{N}$ management.
\end{abstract}

Published by Elsevier B.V.

\section{Introduction}

Nitrogen is the most important nutrient required in cotton. However, cotton is an indeterminate plant, so balancing vegetative and reproductive growth is crucial for crop production. Excess $\mathrm{N}$ application can promote excessive vegetative growth (Gerik et al., 1998), which in turn delays boll maturity (Jackson and Gerik, 1990) and increases susceptibility to disease and boll rot (Oosterhuis, 2001). Insufficient N, on the other hand, limits boll production and yield (Stewart, 1986; Ramey, 1986).

Nitrogen fertilizer has been shown to increase leaf number and leaf area (Bondada et al., 1996), plant height (Gardner and Tucker, 1967), number of nodes (Jackson and Gerik, 1990),

\footnotetext{
* Corresponding author. Present address: Department of Agriculture Technology Universiti Putra Malaysia, UPM, 43400 Serdang, Selangor, Malaysia. Tel.: +60 011522529014 .

E-mail address: kevin.bronson@ars.usda.gov (K.F. Bronson).
}

number of bolls (Jackson and Gerik, 1990; Boquet et al., 1994), and individual boll weight (Bondada et al., 1996). On the other hand, symptoms of $\mathrm{N}$ deficiency are readily identifiable. Nitrogen deficit decreases production of chlorophyll (Radin and Mauney, 1986; Hay and Porter, 2006), causing chlorosis (Stewart et al., 2010) and limiting the photosynthetic capacity of the plant. Leaf expansion is also affected by $\mathrm{N}$ deficiency (Radin and Mauney, 1986), the size of the youngest leaves remains small (Stewart et al., 2010), and the leaf area index remains low (Jackson and Gerik, 1990; Fernandez et al., 1996). Nitrogen-deficit plants characteristically have stunted height, shortened petioles, and thin stalks (Grundon, 1987).

The conventional methods of assessing plant available $\mathrm{N}$ for cotton in the Western US are pre-plant soil $\mathrm{NO}_{3}$ testing, and in-season plant tissue $\mathrm{N}$ and petiole sap $\mathrm{NO}_{3}$ analysis (Silvertooth et al., 2011; Sabbe and Hodges, 2010; Sabbe and Zelinski, 1990). Although these methods are reliable, they are also time-consuming and expensive. The advantages of testing for leaf $\mathrm{N}$ compared to petiole sap for $\mathrm{N}$ concentration analysis in cotton has been reported by several researchers (Read et al., 2002; Buscaglia and Varco, 2002 and 
Bronson et al., 2003). Zhao et al. (2010) found that the seasonal pattern of $\mathrm{N}$ concentrations derived from the entire plant canopy was consistent to the analysis obtained from uppermost, fully expanded leaves. Many researchers have explored the potential of the chlorophyll (SPAD) meter as an alternative method to assess plant N, with varying results (Wood et al., 1992; Bronson et al., 2001). Since chlorophyll contains the majority of $\mathrm{N}$ in leaves (Takebe et al., 1990; Yoder and Pettigrew-Crosby, 1995), leaf $\mathrm{N}$ content can be estimated from leaf chlorophyll concentration. Bronson et al. (2001) reported that SPAD readings were less variable than petiole $\mathrm{NO}_{3}$ meter readings for assessing $\mathrm{N}$ status in cotton at blooming. However, Wiedenfeld et al. (2009) found petiole sap readings to be more closely related to $\mathrm{N}$ rate than leaf $\mathrm{N}$ or SPAD measurements. On the other hand, factors such as crop age, plant species, leaf-soil water status, time of measurement and irradiance level can affect how well SPAD readings do in distinguishing exhibiting $\mathrm{N}$ treatment effects (Wood et al., 1992; Bronson et al., 2001; Wiedenfeld et al., 2009; Martinez and Guiamet, 2004).

Bronson et al. (2003) reported that both leaf $\mathrm{N}$ and SPAD readings could be used to guide $\mathrm{N}$ fertilization rates as early as at squaring. Rosolem and Van Meliss (2010), and Malavolta et al. (2004) found that the efficiency of SPAD in distinguishing $\mathrm{N}$ contents was viable well into flowering. However, the use of SPAD meter still requires the contact with the leaves. The practical application of SPAD meter is limited by time and labor factors when it was used in a large field with high $\mathrm{N}$ variability (Osborne et al., 2002; Peterson et al., 1993).

Plant growth indicators such as plant height has been used to provide estimates of crop yield and $\mathrm{N}$ status, in combination with spectral reflectance of the respective crops. Thenkabail et al. (2000) found that the accuracy in estimating plant height could be improved by using reflectance in narrow spectral wavebands in the red and NIR regions $\left(R^{2}=0.64\right)$. Freeman et al. (2007) developed a 3-dimensional index based on the multiplication of NDVI and plant height to estimate corn biomass at early and later stages $\left(R^{2}=0.66\right.$ and 0.45$)$, yield $\left(R^{2}=0.62\right.$ and 0.64$)$, and $\mathrm{N}$ uptake $\left(R^{2}=0.77\right.$ and 0.46). Liu and Wiatrak (2011) proposed the use of plant height, NDVI and LAI in estimating corn grain yield. Sui and Thomasson (2006) found that plant height in combination with reflectance in visible spectral bands represented the best estimator for cotton $\mathrm{N}$ status $\left(R^{2}=0.50\right.$ to 0.51$)$. Jones et al. (2007) utilized plant height and ground cover measurements to estimate plant biomass for spinach $\left(R^{2}=0.91\right)$. Shaver et al. (2011) reported that the inclusion of plant-related data such as leaf $\mathrm{N}$ content and plant height did not markedly increase the ability of NDVI to estimate corn $\mathrm{N}$ status or grain yield ( $R^{2}$ from 0.88 to 0.95 ). This may be related to the long-standing problem of "saturation" of NDVI at maximum biomass or plant height.

Ground cover or vegetation fraction is defined as the fraction of an area covered with plant canopy (Maas, 1998). Since different $\mathrm{N}$ application rates can induce differences in physiological parameters as such chlorophyll concentration, leaf are index (LAI) and biomass (Milroy et al., 2001; Bronson et al., 2005; Zhao et al., 2007), percent ground cover can also provide information regarding crop growth and health independent of chlorosis. Therefore, ground cover can be a valuable measure of crop growth and $\mathrm{N}$ status. This parameter has been found to be highly correlated with spectral reflectance in multiple crops (Colwell, 1974; Verstraete and Pinty, 1991), including cotton (Huete et al., 1985; Maas, 1997; Ritchie et al., 2010). Jackson et al. (1979) used ground cover and ratio of plant height to width to model the components of spectral reflectance for incomplete canopy covers. In a study to model cotton canopy reflectance by using physiological parameters, Maas (1997) found that canopy width was consistently related to the ratio of leaf area per plant per plant spacing. Maas (1998) also developed and tested a method to estimate cotton ground cover from scene reflectance by accounting for three main reflectance components which were plant, bare soil and shadow. However, there are few studies that explores the effects of ground cover or canopy width on plant $\mathrm{N}$ status.

The objectives of this study were to:

(1) assess the effect of $\mathrm{N}$ fertilizer rate on leaf $\mathrm{N}$, petiole $\mathrm{NO}_{3}$, chlorophyll meter readings plant height, plant width, and ground cover, and to determine inter-correlations among these plant $\mathrm{N}$ indicators and plant growth parameters.

(2) Compare leaf $\mathrm{N}$, petiole $\mathrm{NO}_{3}$, and chlorophyll meter readings as in-season indicators of plant $\mathrm{N}$ status, especially as affected by the plant height, plant width, and ground cover.

\section{Materials and methods}

\subsection{Experimental sites and designs}

In 2010, $\mathrm{N}$ fertilizer experiments were conducted at the Texas Tech University Quaker Avenue Research Farm $\left(33.598^{\circ} \mathrm{N}\right.$, $101.906^{\circ} \mathrm{W}$ ) and the Texas AgriLife Research and Extension Center $\left(33.690^{\circ} \mathrm{N}\right.$ and $\left.101.827^{\circ} \mathrm{W}\right)$, in Lubbock County, Texas. Henceforth, these experimental sites will be referred to as Lubbock and New Deal. In 2011, a study site at the Texas AgriLife and Extension Center in Halfway $\left(34.147^{\circ} \mathrm{N}, 101.948^{\circ} \mathrm{W}\right)$, in Hale County, Texas was used. The soil types at Lubbock, New Deal and Halfway are Acuff sandy clay loam, Lubbock sandy clay, and Pullman clay loam, respectively (USDA-NCRS, 2011). Lubbock was furrow-irrigated, while other experimental sites were irrigated using sub-surface drip irrigation (SDI). At Halfway, the SDI system had drip tape spaced at $2 \mathrm{~m}$ in the middle of alternate furrows at $30-\mathrm{cm}$ depth with emitters spaced at $60 \mathrm{~cm}$. Irrigation for was $1 \mathrm{~L} \mathrm{~min}^{-1}$ at $0.08 \mathrm{MPa}$. Target inseason irrigation, accounting for rain was $90 \%$ evapotranspiration (ET) replacement. Reference ET was calculated with weather data and, and ET was calculated by multiplying cotton crop coefficients by reference ET, which was calculated with a modified Penman Monteith equation (Lascano and Salisbury, 1993).

The experimental design at Lubbock was a randomized block design (RBD) with three levels of $\mathrm{N}$ fertilizer and four replications. At this station, FiberMax 9170 and PHY 375 WRF (PhytoGen 375 WideStrike and Genuity Roundup Ready Flex) were planted on 20 May 2010 and 23 May 2011, respectively, in 16, 1-m rows that were $52 \mathrm{~m}$ long. In 2010 and at 2011, N fertilizer rates were 0, 67 and $134 \mathrm{~kg} \mathrm{ha}^{-1}$ representing zero, intermediate and full $\mathrm{N}$ rates as determined using soil-based tests for recommended yields. The $\mathrm{N}$ was applied as urea ammonium nitrate (UAN) $\left(320 \mathrm{~g} \mathrm{~N} \mathrm{~kg}^{-1}\right)$ split in two equal applications on 25 and 60 days after planting (DAP) 2010. The fertilization was followed immediately by irrigation.

The experiment at New Deal was conducted as a factorial Randomized Incomplete Block Design (RIBD) with three blocks (replicates), where the zero treatment had only two replications. The site was planted on 20 May 2010 with Stoneville 5458 (ST 5458) and FiberMax 9180 (FM 9180) in 8, 1-m row plots that were $180 \mathrm{~m}$ long. There were 3 levels of $\mathrm{N}$ fertilizer in New Deal, a zero-N, intermediate $\mathrm{N}\left(50 \mathrm{~kg} \mathrm{ha}^{-1}\right)$ and full $\mathrm{N}$ rates $\left(101 \mathrm{~kg} \mathrm{ha}^{-1}\right)$ determined as the first reflectance-based $\mathrm{N}$ strategy described in Bronson et al. (2011). Each block consisted of 8 rows that were supplied by an individual irrigation and fertilizer injection station. Nitrogen as urea ammonium nitrate (UAN) ( $320 \mathrm{~g} \mathrm{~N} \mathrm{~kg}^{-1}$ ) was injected through the SDI for five weeks starting from 33 to 64 DAP for five days per week in twenty five equal doses until the total rates were achieved. To ensure optimum pH level of the irrigation water and to avoid precipitation of calcium carbonate, sulfuric acid $\left(250 \mathrm{~g} \mathrm{~kg}^{-1} \mathrm{H}_{2} \mathrm{SO}_{4}\right)$ was injected continuously into the irrigation water. 
The experimental design at Halfway was randomized complete block design (RCBD) with five replicates or blocks. This site was planted with DP 104 B2RF (Delta Pine 104 Bollgard II RoundupReady Flex) in 16 rows by $37 \mathrm{~m}$ plots, on $80-\mathrm{cm}$ row spacing on 14 June 2011. Five rates of $\mathrm{N}$ fertilizer used were $0,56,112,168$ and $224 \mathrm{~kg} \mathrm{ha}^{-1}$. The $\mathrm{N}$ fertilizer was knifed into the soil $10 \mathrm{~cm}$ off the plant row in a one-time UAN application $\left(320 \mathrm{~g} \mathrm{~N} \mathrm{~kg}^{-1}\right)$ with a ground applicator on 3 August 2011 (50 DAP).

The $\mathrm{N}$ fertilizer trials at the three sites had varying $\mathrm{N}$ fertilizer rates because of independent study objectives, In order to better compare $\mathrm{N}$ fertilizer responses among the three sites, we will restrict the discussion to the zero-N plots at all sites, and to the 134 , 101 , and $112 \mathrm{~kg} \mathrm{~N} \mathrm{ha}^{-1}$ rates at Lubbock, New Deal, and Halfway, respectively.

\subsection{Data collection}

In 2010 and 2011, physiological measurements were taken during the period from squaring until the development of first green bolls (mid to peak bloom). Sampling dates were categorized by cotton plant growth stage: squaring, flowering, and first green bolls. In 2010 , due to cooler, wetter conditions delaying growth and resulting in larger plants, physiological data were measured from 9 July to 5 September. In 2011, physiological measurements were made every two weeks from 28 June to 31 August.

The differences in temperature from 2010 to 2011 had a large effect on plant development. At Lubbock in 2010, squaring began at 49 DAP, first bloom was evident at 81 DAP, and first green bolls was at 107 DAP. At New Deal, squaring was at 60 DAPs, flowering at 87 DAP, and the first green bolls were at 108 DAP. In 2011, due to the high heat unit accumulation, the growing season was markedly shortened. At Lubbock, squaring was at 51 DAP, flowering was at 66 DAP, and the first green bolls were at 78 DAP. At Halfway, squaring was at 36 , flowering at 64 , and first green bolls at 78 DAP.

Plant physiological measurements included plant canopy width and height $(\mathrm{cm})$, SPAD reading (SPAD units), petiole sap $\mathrm{NO}_{3}$ $\left(\mu \mathrm{g} \mathrm{mL}^{-1}\right)$, leaf $\mathrm{N}(\%)$, and percent ground cover (determined from overhead photographs). Plant canopy height and width were measured using a standard meter stick. Measurements of plant height and width were made at 25 locations selected randomly within each individual plot. Chlorophyll measurements were made using the Minolta SPAD 502 meter (Minolta Corp., Osaka, Japan) on recently matured fully expanded leaves harvested from 25 plants. The petioles from all of the 25 leaves were separated from their blades immediately, and were stored in an iced cooler for sap $\mathrm{NO}_{3}$ measurement, which was made within eight hours of leaf harvest. The leaf blades were also kept for leaf total $\mathrm{N}$ analysis. Nadir viewing images of the cotton rows were taken using a digital camera (Eastman Kodak Co., Rochester, NY) attached to an adjustable pole at approximately $3 \mathrm{~m}$ above the plant canopy for use in determining percent ground cover.

Weather data, including measurements of rainfall, maximum and minimum air temperature, were obtained from observations made by the Texas Tech West Texas Mesonet weather station network (http://mesonet@ttu.edu).

\subsection{Plant sap $\mathrm{NO}_{3}$ and leaf $\mathrm{N}$ analysis}

Plant sap $\mathrm{NO}_{3}$ measurements were made using a Cardy $\mathrm{NO}_{3}$ Meter (Spectrum Technologies, Inc., Plainfield, IL). A two-point sensor calibration using standardized solutions was performed prior to $\mathrm{NO}_{3}$ measurement. Sap samples were collected from leaf petioles on the recently matured fully expanded leaf or the fifth leaf from the top of each plant. Petioles were removed from leaves in the field and stored in a zip-lock plastic bag. In the lab, the petioles were carefully crushed using a mortar and pestle, without tearing the plastic bag. A corner of the plastic bag was punctured, and the sap was squeezed out into a small plastic container. A syringe was used to take up $1 \mathrm{~mL}$ of the sap, which was then diluted with $9 \mathrm{~mL}$ of distilled water taken up by the same syringe. The diluted solution was placed on the flat sensor surface between the electrodes, and readings were taken $30 \mathrm{~s}$ after the solution had been placed on the sensor. The readings were then multiplied by 10 to account for the dilution. All of the instruments used in these procedures were washed using distilled water to avoid contamination from previously processed samples.

The leaf blades were dried at $65^{\circ} \mathrm{C}$ for $96 \mathrm{~h}$ and ground to $0.5 \mathrm{~mm}$. In 2010, a LECO FP-528 Protein N Analyzer (LECO Corp., St. Joseph, MI) was used to perform this analysis, and a LECO Tru-Spec CN (LECO Corp., St. Joseph, MI) was used in 2011.

\subsection{Ground cover estimation}

To estimate the percent ground cover, images obtained using a Kodak (Eastman Kodak Company, Rochester, NY) digital camera were processed using Adobe Photoshop 7.0 (Adobe System Inc., San Jose, CA). Images were rotated accordingly if the plant rows were not perpendicular to the bottom or upper edges of the images. A central portion of each image was cropped to a square area that extended across one row of plants from the center of one furrow to the center of next furrow ( $0.8 \mathrm{~m}$ at Halfway, $1 \mathrm{~m}$ at Lubbock and New Deal). The purpose of the cropping was to minimize the effects of perspective distortion along the edges of the images. Canopy pixels were selected using the Select Range toolbox function, and manual editing was performed following the procedure to eliminate volunteer cotton plants, weeds, plant litter or shadows. The number of pixels representing plant canopy was obtained using the Histogram function. To determine the total number of pixels in the image, the image size width (pixel) were multiplied with height (pixel). Finally, the percent ground cover was determined by dividing the number of pixels presenting the plant canopy by the total number of pixels in the image, and multiplying this value by 100 .

\subsection{Statistical analysis}

All three plant $\mathrm{N}$ indicator and all three plant parameter data were tested for $\mathrm{N}$ treatment effects $(P<0.05)$ using the PROC GLIMMIX in SAS Ver. 9.3 (SAS Institute, 2013). This analysis of variance (ANOVA) was conducted at individual experimental sites and year as a RBD design. The ANOVA were analyzed by sampling dates rather than by the entire season, as Buscaglia and Varco (2002) found that the relationship between leaf reflectance and leaf $\mathrm{N}$ concentration is significantly growth-stage dependent. Replicate was considered random and $\mathrm{N}$ rate fixed. Cultivar was included as a fixed effect in New Deal in 2010. Simple correlation was performed with all plant data (leaf N, petiole NO3, SPAD readings, plant height, plant width, and ground cover) using PROC CORR by date, and also with pooled season data. Due to the different experimental designs at the three sites, we did not attempt to performed statistical analysis across sites.

\section{Results}

\subsection{Environmental conditions and irrigation}

Growing conditions in 2010 were abnormally wet and cool, while in 2011 they were extremely dry and hot as compared to historical data (Fig. 1). In 2010, precipitation was above normal prior to the growing season, and heavy rainfall events also occurred in April, July and October. In addition, temperatures throughout 2010 were lower than the 10-year average. 


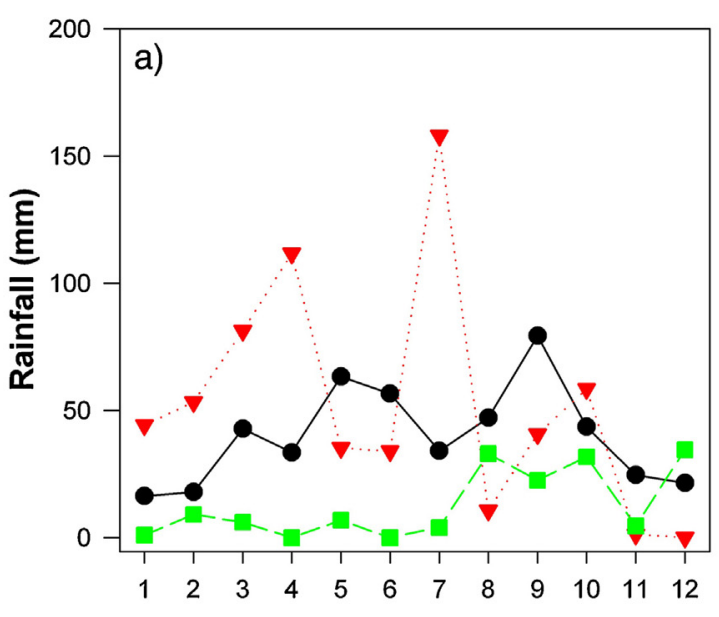

Month

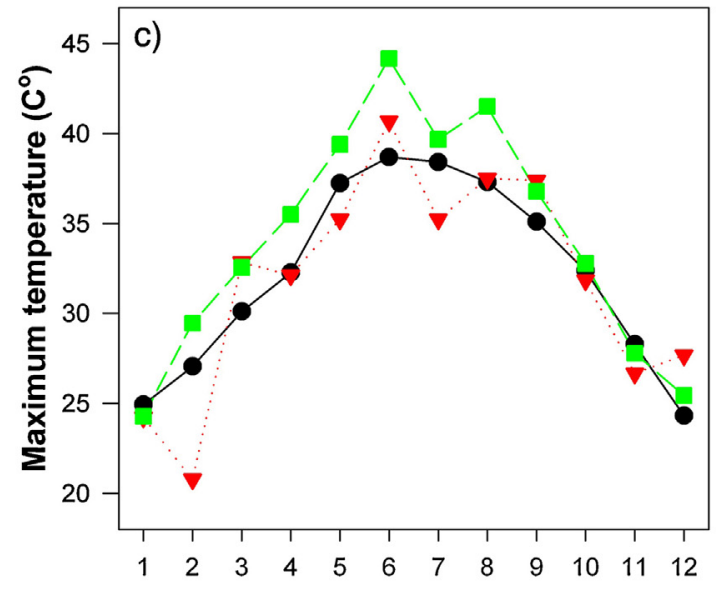

Month

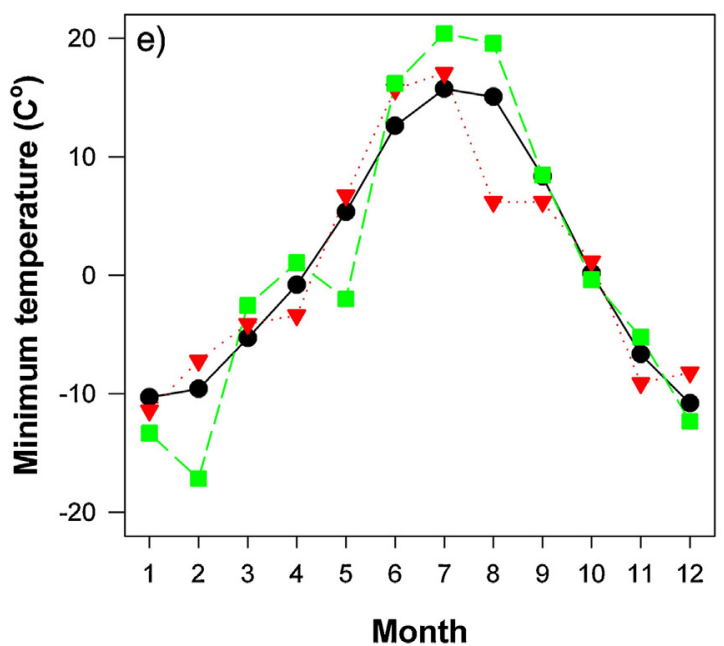

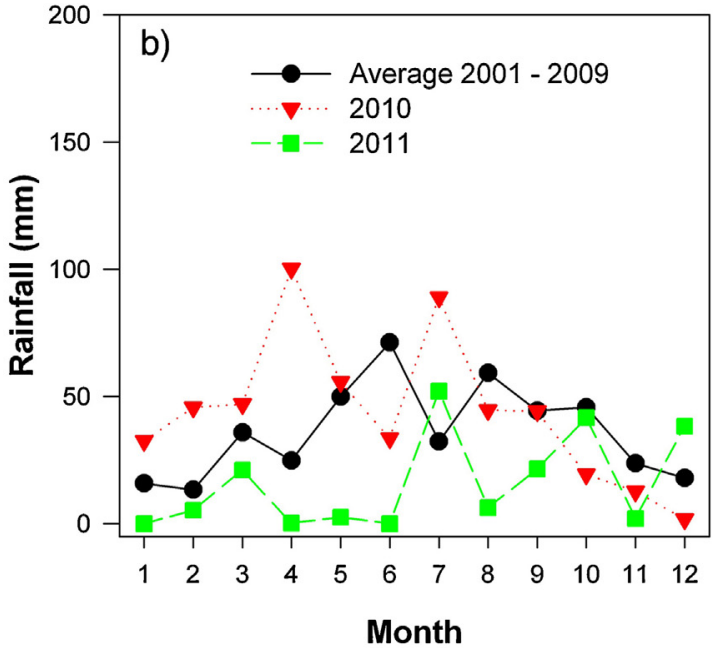

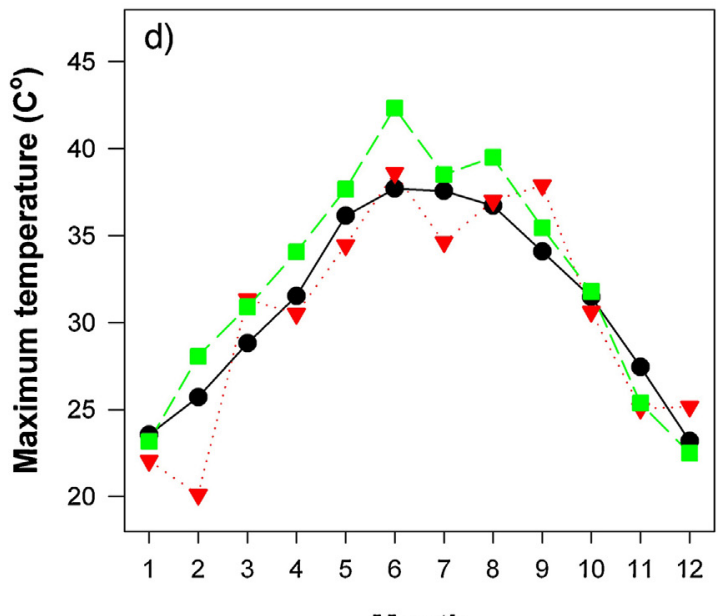

Month

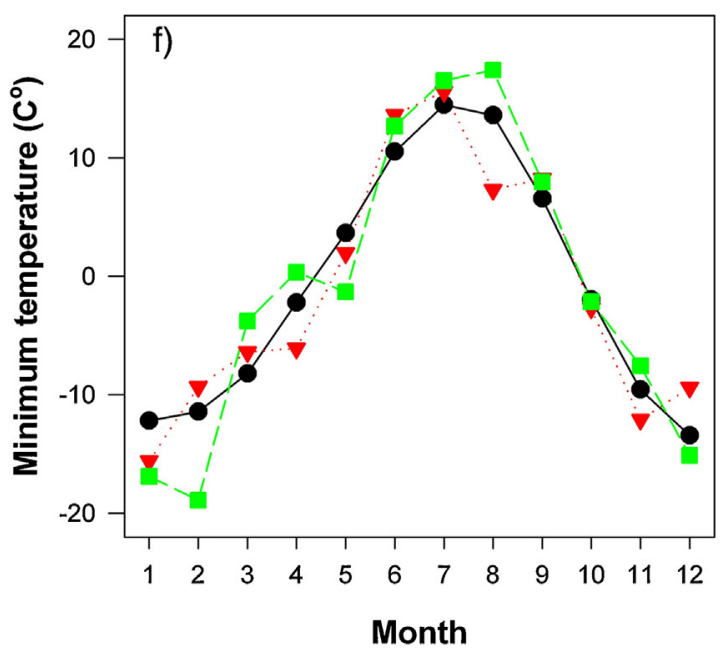

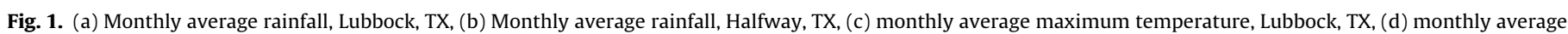
maximum temperature, Halfway, TX (e) monthly average minimum temperature at Lubbock, TX and (f) monthly average minimum temperature at Halfway, TX. 
Table 1

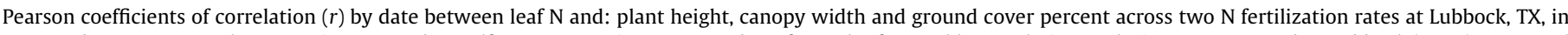

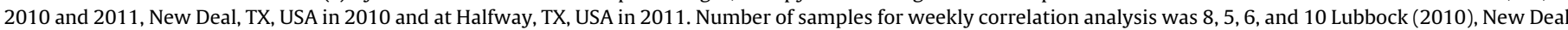
(2010) (each cultivars), Lubbock (2011) and Halfway (2011), respectively.

\begin{tabular}{|c|c|c|c|c|}
\hline Cultivar, site, year & DAP & Plant height $(\mathrm{cm})$ & Canopy width $(\mathrm{cm})$ & Ground cover (\%) \\
\hline \multirow{7}{*}{ FM 9170, Lubbock, 2010} & 49 & & & \\
\hline & 54 & & $0.70^{*}$ & $0.77^{* *}$ \\
\hline & 61 & $0.88^{* *}$ & $0.78^{* *}$ & $0.93^{* *}$ \\
\hline & 68 & & $0.65^{*}$ & \\
\hline & 81 & & & $0.64^{*}$ \\
\hline & 96 & & $0.71^{* *}$ & $0.87^{* *}$ \\
\hline & 107 & & & \\
\hline \multirow[t]{5}{*}{ ST5458, New Deal, 2010} & 60 & $0.92^{* *}$ & & $0.95^{* *}$ \\
\hline & 69 & $0.85^{*}$ & $0.88^{*}$ & $0.94^{* *}$ \\
\hline & 87 & & $0.81^{*}$ & $0.94^{* *}$ \\
\hline & 96 & $0.98^{* *}$ & $0.95^{* *}$ & $0.87^{*}$ \\
\hline & 108 & $0.89^{* *}$ & $0.94^{* *}$ & $0.94^{* *}$ \\
\hline \multirow[t]{5}{*}{ FM 9180, New Deal, 2010} & 60 & $0.99^{* *}$ & $0.85^{*}$ & $0.92^{* *}$ \\
\hline & 69 & $0.93^{* *}$ & $0.95^{* *}$ & $0.95^{* *}$ \\
\hline & 87 & $0.99^{* *}$ & $0.91^{* *}$ & $0.96^{* *}$ \\
\hline & 96 & $0.97^{* *}$ & $0.94^{* *}$ & $0.99^{* *}$ \\
\hline & 108 & $0.98^{* *}$ & $0.95^{* *}$ & $0.93^{* *}$ \\
\hline \multirow[t]{4}{*}{ PHY 375, Lubbock, 2011} & 51 & & & \\
\hline & 66 & $0.77^{*}$ & $0.71^{*}$ & $0.73^{*}$ \\
\hline & 79 & $0.88^{* *}$ & $0.84^{* *}$ & $0.75^{*}$ \\
\hline & 89 & & & \\
\hline \multirow[t]{5}{*}{ DP104, Halfway, 2011} & 36 & & & $0.57^{*}$ \\
\hline & 51 & & & $0.71^{* *}$ \\
\hline & 64 & & & $0.60^{*}$ \\
\hline & 72 & & & \\
\hline & 78 & $0.67^{* *}$ & $0.69^{* *}$ & $0.82^{* *}$ \\
\hline
\end{tabular}

, ${ }^{* *}$ Significant levels ( $P$-value) at 0.05 , and 0.01 , respectively. DAP is days after planting.

Rainfall and irrigation in Lubbock in 2010 and in 2011, were $213,220,42$, and $480 \mathrm{~mm}$, respectively. These equaled ET replacement at Lubbock as 90 and 65\% in 2010 and 2011, respectively. At New Deal in 2010, in-season irrigation and rainfall was 196, and $249 \mathrm{~mm}$, respectively, or about 93\% of ET. In Halfway in 2011, inseason irrigation and rainfall was 453 , and $49 \mathrm{~mm}$, respectively, or about $75 \%$ ET replacement. Weed, pest, and disease pressure was low at all site-years.

\subsection{Plant $N$ indicators}

Leaf $\mathrm{N}$ was growth stage-dependent, and was also significantly affected by $\mathrm{N}$ fertilization $(P<0.05)$ at all five cultivar-site-years. Leaf $\mathrm{N}$ content responded positively to and reflected the two $\mathrm{N}$ fertilizer rates, except for Lubbock in 2011 at 51 DAP (Figs. 2a, 3a, 4a, $5 \mathrm{a}$ and $6 \mathrm{a}$ ). In 2010, leaf $\mathrm{N}$ at Lubbock and New Deal (both cultivars) had initially low leaf $\mathrm{N}$ at squaring, which increased to reach a maximum at flowering before decreasing slightly at green bolls (Figs. 2a, 3a and 4a). In contrast, the leaf $\mathrm{N}$ pattern at Lubbock and Halfway in 2011 was characterized by high leaf $\mathrm{N}$ content early in the season that declined as the season progressed (Figs. 5a and $6 a)$.

Figs. $2 \mathrm{~b}, 3 \mathrm{~b}, 4 \mathrm{~b}, 5 \mathrm{~b}$ and $6 \mathrm{~b}$ show the pattern of petiole sap $\mathrm{NO}_{3}$ readings throughout the growing seasons. The high $\mathrm{N}$ treatment resulted in highest petiole sap $\mathrm{NO}_{3}$ contents, followed by the medium and zero- $\mathrm{N}$ treatments. However, petiole $\mathrm{NO}_{3}$ for the $\mathrm{N}$ fertilized plots at Lubbock and Halfway in 2011 began the season at low levels, compared to the 2010 sites. After squaring, petiole sap readings for the different $\mathrm{N}$ rates started to decline and converged on similar, low values. In the first half of the season, the sap $\mathrm{NO}_{3}$ at all sites showed a greater $\mathrm{N}$ rate effect than did SPAD readings or leaf $\mathrm{N}$ levels. On the other hand, petiole $\mathrm{NO}_{3}$ declined much more rapidly than did leaf $\mathrm{N}$ or SPAD, which limits its late-season utility. For example, at New Deal, in 2010 petiole $\mathrm{NO}_{3}$ in both cultivars had gone down to very low level by 86 DAP.

Chlorophyll content, as measured by SPAD meter readings, was also significantly influenced by the $\mathrm{N}$ treatments and growth stages $(P<0.05)$. SPAD measurements also reflected $N$ rates (Figs. $2 c, 3 c, 4 c$, $5 \mathrm{c}$ and $6 \mathrm{c}$ ). Compared to leaf $\mathrm{N}$, SPAD readings showed a smoother seasonal pattern. At Lubbock (both years) and New Deal (both cultivars), the initially low chlorophyll content increased gradually as the season progressed, with the maximum readings achieved at flowering (Figs. 2c, 3c, 4c and 5c). On the other hand, the pattern was reversed at Halfway (2011), chlorophyll content that was initially high at squaring declined steadily toward plant maturity (Fig. 6c).

\subsection{Plant growth parameters}

Plant height, width and ground cover were affected by $\mathrm{N}$ treatments and growth stage in both years (Figs. 2d, 3d, 4d, 5d and 6d). Cotton plants grew taller at Lubbock and New Deal in wet 2010 conditions compared to the dry year at Lubbock and Halfway in 2011. Soil types at Lubbock and New Deal were the same, but the soil at Halfway had a greater clay content. Never-the-less, it is clear that the reduced plant height and other growth parameters at Lubbock and Halfway sites in 2011 were due to the deficit irrigation of 65 and 75\% ET replacement, respectively. For all of the cultivars, plant height increased as the season progressed, with the most rapid growth occurring prior to flowering. After flowering, growth decreased and plant height remained relatively constant. Plant height at Lubbock (2010) responded positively to $\mathrm{N}$ fertilization rates on 49,61,68, and 96 DAP only. At New Deal (2010), plant heights of two $\mathrm{N}$-fertilized treatments were significantly greater 
Table 2

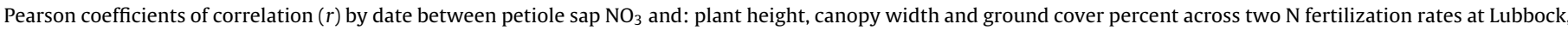

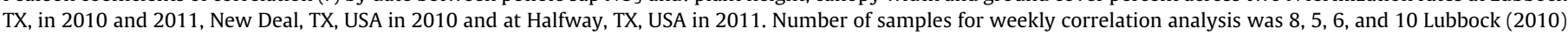
New Deal (2010) (each cultivars), Lubbock (2011) and Halfway (2011), respectively.

\begin{tabular}{|c|c|c|c|c|}
\hline Cultivar, site, year & DAP & Plant height $(\mathrm{cm})$ & Canopy width (cm) & Ground cover (\%) \\
\hline \multirow[t]{7}{*}{ FM9170, Lubbock, 2010} & 49 & & & $0.69^{*}$ \\
\hline & 54 & & $0.73^{* *}$ & $0.74^{* *}$ \\
\hline & 61 & $0.68^{*}$ & $0.79^{* *}$ & $0.79^{* *}$ \\
\hline & 68 & & $0.79^{* *}$ & $0.68^{*}$ \\
\hline & 81 & & & \\
\hline & 96 & $0.67^{*}$ & $0.87^{* *}$ & $0.85^{* *}$ \\
\hline & 107 & & & \\
\hline \multirow[t]{5}{*}{ ST5458, New Deal, 2010} & 60 & $0.86^{*}$ & & $0.94^{* *}$ \\
\hline & 69 & $0.85^{*}$ & $0.86^{*}$ & $0.94^{* *}$ \\
\hline & 87 & & & \\
\hline & 96 & & & \\
\hline & 108 & & & \\
\hline \multirow[t]{5}{*}{ FM9180, New Deal, 2010} & 60 & $0.97^{* *}$ & & $0.96^{* *}$ \\
\hline & 69 & $0.85^{*}$ & $0.89^{* *}$ & $0.87^{*}$ \\
\hline & 87 & & & $0.81^{*}$ \\
\hline & 96 & & & \\
\hline & 108 & & & \\
\hline \multirow[t]{4}{*}{ PHY375, Lubbock, 2011} & 51 & $0.77^{*}$ & & $-0.92^{* *}$ \\
\hline & 66 & $0.83^{* *}$ & $0.84^{* *}$ & \\
\hline & 79 & & & \\
\hline & 89 & & & \\
\hline \multirow[t]{5}{*}{ DP104, Halfway, 2011} & 36 & & & \\
\hline & 51 & & $0.63^{*}$ & \\
\hline & 64 & $0.59^{*}$ & $0.60^{*}$ & $0.64^{*}$ \\
\hline & 72 & & & \\
\hline & 78 & $0.89^{* *}$ & $0.85^{* *}$ & $0.67^{* *}$ \\
\hline
\end{tabular}

"** Denote non-significant and significant levels ( $P$-value) at 0.05 , and 0.01 , respectively. DAP is Days after planting.

than in the zero-N plots at all DAP. In 2011, plant heights at Lubbock were significantly different for all $\mathrm{N}$ treatments at 66 and 79 DAP only. Plant height at Halfway (2011) showed significant $\mathrm{N}$ effects only after 66 DAP.

Canopy width showed a similar seasonal and $\mathrm{N}$ rate pattern to plant height (Figs. 2d, 3d, 4d, 5d and 6d). Although the general pattern was that canopy width increased steadily as plants matured, rapid increases in canopy width were observed at squaring (69 DAP in 2010 and 66 DAP in 2011). Canopy width reached a temporary maximum at flowering before increasing again at green bolls, due to the spreading of branches under the weight of bolls as they were produced and filled. Plots with high $\mathrm{N}$ rates produced wider plants that zero-N plots. The maximum canopy width in 2011 was onethird shorter than the maximum canopy width in 2010 , reflecting the greater water deficit in 2011. In 2010, the maximum canopy width at Lubbock and New Deal (both cultivars) ranged from 97.6 to $107.1 \mathrm{~cm}$. However, the maximum width at Lubbock and Halfway in 2011 were only two-third of the width in 2010, which were 60.3 and $61.5 \mathrm{~cm}$. Reduced canopy width in 2011, as discussed above for plant height was likely due to drought, and less to other factors such as cultivars or soil type.

Of all physiological plant parameters measured, ground cover illustrated the most consistent trend among the sampling dates (Figs. 2f, 3f, 4f, $5 \mathrm{f}$ and $6 \mathrm{f}$ ). Ground cover measured at the two $\mathrm{N}$ rates at all stations were significantly different from each other at most of the sampling dates, except for 49 (2010) and 51 DAP (2011) at Lubbock. As the season progressed, ground cover steadily increased, with a smoother pattern than canopy width. Plots receiving the high $\mathrm{N}$ rate showed a gradual increase in ground cover throughout the growing season. For the zero $\mathrm{N}$ rate, this increase was smaller. Similar to the pattern observed in canopy width, maximum ground cover in 2011 was considerably lower than in 2010. Maximum ground cover (58 and $68 \mathrm{~cm}$ ) in 2011 at both Lubbock and Halfway was only three-quarter of the maximum ground cover $(82.2$ to $89.4 \mathrm{~cm})$ in 2010 at Lubbock and New Deal (both cultivars). The hot, dry weather that had caused water deficit conditions in 2011 clearly affected ground cover at Lubbock and Halfway.

\subsection{Correlations among plant $N$ indicators and growth parameters}

Leaf $\mathrm{N}$ had large positive correlations with the three plant parameters at many of the dates sampled in the five cultivar-siteyears (Table 1). Canopy width and ground cover were positively related to leaf $\mathrm{N}$ at more sampling dates than plant height. The SDI-irrigated cultivars at New Deal in 2010 had the most frequent number of dates with high correlations.

Petiole $\mathrm{NO}_{3}$ correlations with plant parameters were less common than with leaf $\mathrm{N}$ (Table 2). The furrow-irrigated Lubbock site in 2010 had many dates of positive correlations between petiole $\mathrm{NO}_{3}$ and canopy width and ground cover, and few with plant height. Ground cover was negatively related to petiole $\mathrm{NO}_{3}$ at 51 DAP in Lubbock.

SPAD readings correlations with plant parameters were similar to those of leaf $\mathrm{N}$, with more correlations at sampling dates at Lubbock in 2010 (Table 3). Ground cover was negatively related to SPAD readings at 51 DAP in Lubbock, 2011, as petiole $\mathrm{NO}_{3}$ was.

Correlation analysis between plant $\mathrm{N}$ indicators and plant parameters was also performed by pooling the data across sampling dates for each of the five cultivar-site-years (Tables 4-6). Seasonwide correlation between leaf $\mathrm{N}$ was positive for the three 2010 cultivar-sites, and was negative for the two 2011 sites (Table 4).

Petiole $\mathrm{NO}_{3}$ had few correlations with plant parameters across the season, with the exception of the negative correlations with plant height, canopy width, and ground cover at Halfway in 2011 (Table 5).

SPAD readings had positive season-wide correlations with all three plant parameters for Lubbock and New Deal in 2010 (Table 6). Weaker positive correlations were observed at Lubbock in 2011 
Table 3

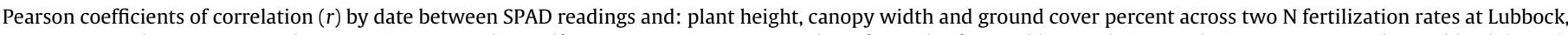

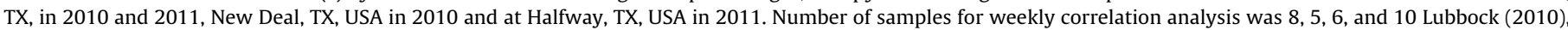
New Deal (2010) (each cultivars), Lubbock (2011) and Halfway (2011), respectively.

\begin{tabular}{|c|c|c|c|c|}
\hline Cultivar, site, year & DAP & Plant height (cm) & Canopy width $(\mathrm{cm})$ & Ground cover (\%) \\
\hline \multirow[t]{7}{*}{ FM 9170, Lubbock, 2010} & 49 & & & \\
\hline & 54 & & $0.73^{* *}$ & $0.75^{* *}$ \\
\hline & 61 & $0.78^{* *}$ & $0.84^{* *}$ & $0.77^{* *}$ \\
\hline & 68 & & $0.81^{* *}$ & $0.70^{*}$ \\
\hline & 81 & & $0.68^{*}$ & $0.81^{* *}$ \\
\hline & 96 & & $0.63^{*}$ & $0.74^{* *}$ \\
\hline & 107 & & & \\
\hline \multirow[t]{5}{*}{ ST5458, New Deal, 2010} & 60 & $0.91^{* *}$ & $0.92^{* *}$ & $0.89^{* *}$ \\
\hline & 69 & $0.90^{* *}$ & $0.87^{*}$ & $0.96^{* *}$ \\
\hline & 87 & & $0.81^{*}$ & $0.93^{* *}$ \\
\hline & 96 & $0.98^{* *}$ & $0.95^{* *}$ & $0.93^{*}$ \\
\hline & 108 & & $0.83^{*}$ & $0.84^{*}$ \\
\hline \multirow{5}{*}{ FM 9180, New Deal, 2010} & 60 & $0.95^{* *}$ & $0.94^{* *}$ & $0.83^{*}$ \\
\hline & 69 & $0.94^{* *}$ & $0.93^{* *}$ & $0.96^{* *}$ \\
\hline & 87 & $0.94^{* *}$ & $0.95^{* *}$ & $0.96^{* *}$ \\
\hline & 96 & $0.96^{* *}$ & $0.92^{* *}$ & $0.98^{* *}$ \\
\hline & 108 & $0.83^{*}$ & $0.96^{* *}$ & $0.90^{* *}$ \\
\hline \multirow[t]{4}{*}{ PHY 375, Lubbock, 2011} & 51 & $0.94^{* *}$ & $-0.74^{*}$ & $-0.81^{*}$ \\
\hline & 66 & & & $0.91^{* *}$ \\
\hline & 79 & $0.83^{* *}$ & & \\
\hline & 89 & & & \\
\hline \multirow[t]{5}{*}{ DP104, Halfway, 2011} & 36 & & & \\
\hline & 51 & & $0.68^{* *}$ & $0.74^{* *}$ \\
\hline & 64 & & & \\
\hline & 72 & $0.62^{*}$ & & $0.71^{* *}$ \\
\hline & 78 & & & \\
\hline
\end{tabular}

", ${ }^{* *}$ Denote significant levels ( $P$-value) at 0.05 , and 0.01, respectively. DAP is Days after planting.

Table 4

Pearson coefficients of correlation ( $r$ ) for all dates between leaf $\mathrm{N}$ and: plant height, canopy width and ground cover percent across two $\mathrm{N}$ fertilization rates at Lubbock, TX, in 2010 and 2011, New Deal, TX, USA in 2010 and at Halfway, TX, USA in 2011. Number of samples for pooled correlation analysis was 50, 25, 30, and 50 Lubbock (2010), New Deal (2010) (each cultivars), Lubbock (2011) and Halfway (2011), respectively.

\begin{tabular}{llcc}
\hline Cultivar, site, year & $\begin{array}{l}\text { Plant } \\
\text { height }(\mathrm{cm})\end{array}$ & $\begin{array}{l}\text { Canopy } \\
\text { width }(\mathrm{cm})\end{array}$ & $\begin{array}{c}\text { Ground } \\
\text { cover }(\%)\end{array}$ \\
\hline FM 9170, Lubbock, 2010 & $0.53^{* *}$ & $0.47^{* *}$ & $0.61^{* *}$ \\
ST5458, New Deal 2010 & $0.77^{* *}$ & $0.60^{* *}$ & $0.82^{* *}$ \\
FM 9180, New Deal, 2010 & $0.80^{* *}$ & $0.56^{* *}$ & $0.85^{* *}$ \\
PHY 375, Lubbock, 2011 & $-0.62^{* *}$ & $-0.46^{* *}$ & $-0.42 V^{* *}$ \\
DP104, Halfway, 2011 & $-0.75^{* *}$ & $-0.69^{* *}$ & $-0.67^{* *}$ \\
\hline
\end{tabular}

*, ${ }^{* *}$ Denote non-significant and significant levels ( $P$-value) at 0.05 , and 0.01 , DAP is Days after planting. between SPAD readings and plant height and width. A small negative correlation was noted between SPAD readings and plant height at Halfway in 2011.

\section{Discussion}

Plant responses to $\mathrm{N}$ treatments were considerably different in 2010 and 2011. The main factor causing this difference was the weather. In weather years that are closer to the long-term averages in terms of temperatures and rain, irrigated cotton farmers in West Texas can grow high-producing crops under a modest deficit irrigation. Limited well capacities meant that in the unusually hot and dry 2011 growing season, these deficits (in our case 65 to $75 \%$ ET replacement) were severe and cotton growth was poor. In 2010, in which water was not a limiting factor, the effects of $\mathrm{N}$ fertilizer were strong and consistent between the zero- $\mathrm{N}$ and $\mathrm{N}$ fertilized plots. The effects were more pronounced in the plant $\mathrm{N}$ indicators, especially leaf $\mathrm{N}$ and SPAD readings. In 2011, the weaker

Table 6

Pearson coefficients of correlation $(r$ ) for all dates between SPAD readings and: plant height, canopy width and ground cover percent across two $\mathrm{N}$ fertilization rates at Lubbock, TX, in 2010 and 2011, New Deal, TX, USA in 2010 and at Halfway, TX, USA in 2011. Number of samples for pooled correlation analysis was 50, 25, 30, and 50 Lubbock (2010), New Deal (2010) (each cultivars), Lubbock (2011) and Halfway (2011), respectively.

\begin{tabular}{llll}
\hline Cultivar, site, year & $\begin{array}{l}\text { Plant } \\
\text { height }(\mathrm{cm})\end{array}$ & $\begin{array}{l}\text { Canopy } \\
\text { width }(\mathrm{cm})\end{array}$ & $\begin{array}{l}\text { Ground } \\
\text { cover (\%) }\end{array}$ \\
\hline FM 9170, Lubbock, 2010 & $0.78^{* *}$ & $0.84^{* *}$ & $0.82^{* *}$ \\
ST5458, New Deal, 2010 & $0.87^{* *}$ & $0.91^{* *}$ & $0.87^{* *}$ \\
FM 9180, New Deal, 2010 & $0.92^{* *}$ & $0.87^{* *}$ & $0.87^{* *}$ \\
PHY 375, Lubbock, 2011 & $0.37^{*}$ & $0.54^{* *}$ & \\
DP104, Halfway, 2011 & $-0.27^{*}$ & & \\
\hline
\end{tabular}

${ }^{*},{ }^{* *}$ Denote non-significant and significant levels ( $P$-value) at 0.05 , and 0.01 , respectively. DAP is Days after planting.

\begin{tabular}{llll}
\hline Cultivar, site, year & $\begin{array}{l}\text { Plant } \\
\text { height }(\mathrm{cm})\end{array}$ & $\begin{array}{l}\text { Canopy } \\
\text { width }(\mathrm{cm})\end{array}$ & $\begin{array}{l}\text { Ground } \\
\text { cover (\%) }\end{array}$ \\
\hline $\begin{array}{l}\text { FM 9170, Lubbock, 2010 } \\
\text { ST5458, New Deal, 2010 }\end{array}$ & $-0.25^{*}$ & & \\
FM 9180, New Deal, 2010 & & & \\
PHY 375, Lubbock, 2011 & & $-0.48^{* *}$ & $-0.30^{* *}$ \\
DP104, Halfway, 2011 & $-0.35^{* *}$ & -0.01, respec \\
\hline
\end{tabular}

${ }^{* * *}$ Denote non-significant and sig
tively. DAP is Days after planting.
Pearson coefficients of correlation $(r)$ for all dates between petiole sap NO3 and: plant height, canopy width and ground cover percent across two $\mathrm{N}$ fertilization rates 50 Lubbock (2010), New Deal (2010) (each cultivars), Lubbock (2011) and Haif (2011), respectively

tively. DAP is Days after planting. 

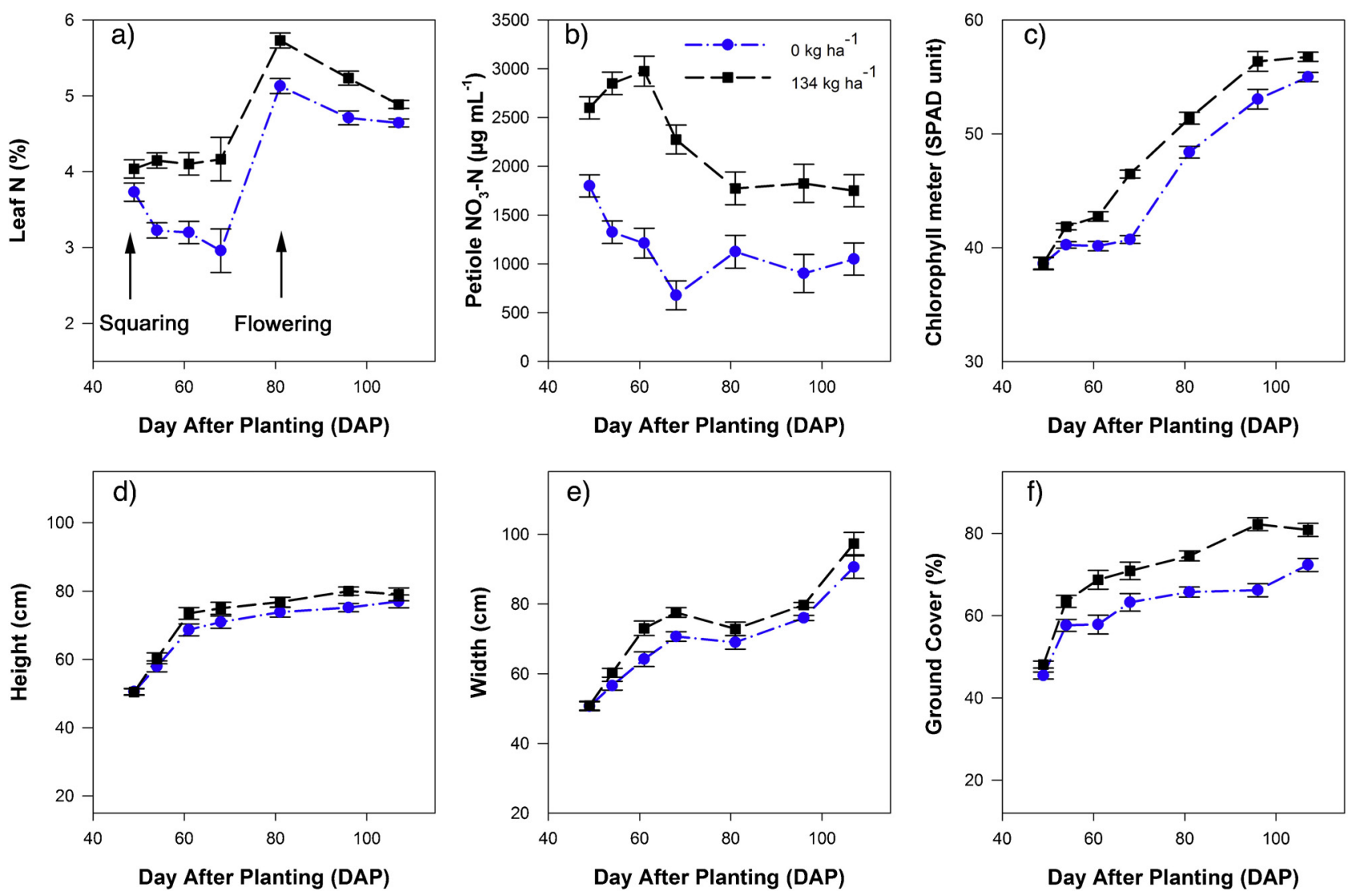

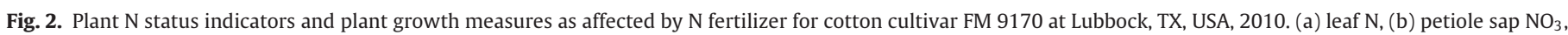
(c) SPAD readings, (d) plant height, (e) canopy width, and (f) percent ground cover.

differences among the $\mathrm{N}$ treatments, and the low plant height, width, and ground covers, reflected the greater water deficit. Burke and Wanjura (2010) reported that, under high air temperatures, leaf area index, plant height and dry matter accumulation were less. Under the limiting water condition, leaf biomass expressed as ground cover is also reduced, due to limited leaf expansion and growth (Radin and Mauney, 1986).Water deficits in West Texas cotton production lower yield and limit the response to $\mathrm{N}$ fertilizer (Bronson et al., 2001). In the wet year of 2010, plant growth parameters were notably larger in the SDI-irrigation at New Deal compared to Lubbock. This reflects slightly larger ET replacement and the greater efficiency of SDI to furrow irrigation (Mateos et al., 1991). The similarity between the cultivars FM 9170 and FM 9180 make this a fair comparison.

One of our objectives was to compare plant N status indicators. Examining the magnitude of the differences in readings between the zero- $\mathrm{N}$ and the $\mathrm{N}$ fertilized plots is useful. The $\mathrm{N}$ rates among the sites were similar enough to make comparisons. Generally speaking, leaf $\mathrm{N}$ and petiole $\mathrm{NO}_{3}$ had similar relative differences between zero- $\mathrm{N}$ and fertilized plots. These $\mathrm{N}$ effects for petiole $\mathrm{NO}_{3}$ were larger than $\mathrm{N}$ effects for leaf $\mathrm{N}$ at Lubbock, 2010 (Fig. 2), and Lubbock 2011 (Fig. 5). A marked difference in the plant $\mathrm{N}$ measures is that petiole $\mathrm{NO}_{3}$ declines very rapidly compared to leaf $\mathrm{N}$ or SPAD readings. At New Deal in 2011, petiole $\mathrm{NO}_{3}$ had crashed by early bloom (Figs. 3 and 4). This greatly reduces the usefulness of petiole $\mathrm{NO}_{3}$. Yabaji et al. (2009) reported that $\mathrm{N}$ fertilizer applications in SDI-irrigated cotton in West Texas are not effective after mid-bloom.

SPAD meter readings were also good indicators of $\mathrm{N}$ status in these studies. In Lubbock, 2010, SPAD meter readings showed a smoother seasonal trend than leaf $\mathrm{N}$ or petiole $\mathrm{NO}_{3}$. However at that site-year, SPAD readings did not show a significant $\mathrm{N}$ effect at squaring as leaf $\mathrm{N}$ and petiole $\mathrm{NO}_{3}$ did. Wiedenfeld et al. (2009) and Bronson et al. (2001), reported that $\mathrm{N}$ effects exhibited in the SPAD readings could be confounded by variations in to soil moisture. In Lubbock, 2011, SPAD readings and leaf $\mathrm{N}$ both did not show a significant $\mathrm{N}$ effect at squaring, but petiole $\mathrm{NO}_{3}$ did. However, in that site year, plant growth was stunted due to drought, and it is unlikely that $\mathrm{N}$ fertilizer was needed. Therefore, the application of $\mathrm{N}$ fertilizer under the dry soil conditions of 2011 offered less benefit because of the limited plant uptake (Zelinski, 1996).

Another objective of this study was to assess the effect of the three plant growth parameters on the three plant $\mathrm{N}$ indicators. The pooled correlation analysis can assist us here. With the exception of Halfway, 2011, petiole $\mathrm{NO}_{3}$ was the $\mathrm{N}$ measure that was least sensitive to plant growth parameters (Table 5). Leaf $\mathrm{N}$ and SPAD readings were mostly positively correlated with plant height, canopy width and ground cover (Tables 4 and 6). The negative correlations between leaf $\mathrm{N}$ and the three plant parameters at Lubbock and Halfway in 2011 was because leaf $\mathrm{N}$ in the dry year never increased early in the season, but just declined season long (Table 4 and Figs. 5 and 6). The same trend and explanation applied to the negative correlation between petiole $\mathrm{NO}_{3}$ and plant parameters in Halfway in 2011 (Table 5 and Fig. 6). In the normal rainfall 2010 year, leaf $\mathrm{N}$ showed the expected latter-season decline from a midseason maximum (Figs. 2-4). The large boll loads we noted visually for both cultivars at New Deal in 2010 likely contributed to this as $\mathrm{N}$ is mobilized from leaf to seed. Curiously, SPAD readings only declined late season for ST 5458 in New Deal, but not with FM 9180 in New Deal or with FM 9170 in Lubbock. This also raises the issue 

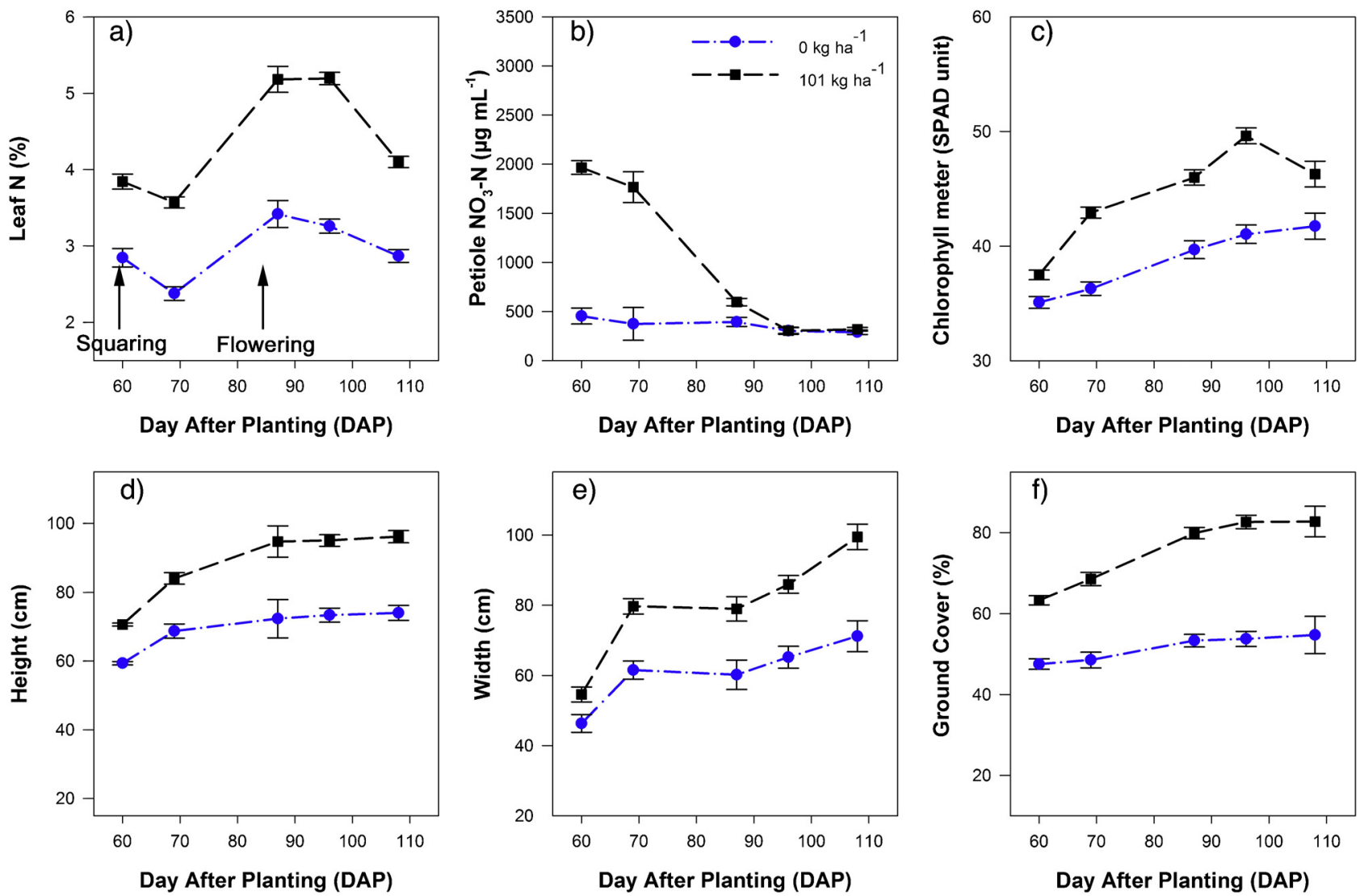

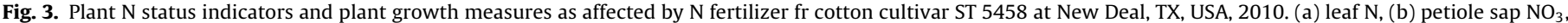
(c) SPAD readings, (d) plant height, (e) canopy width, and (f) percent ground cover.
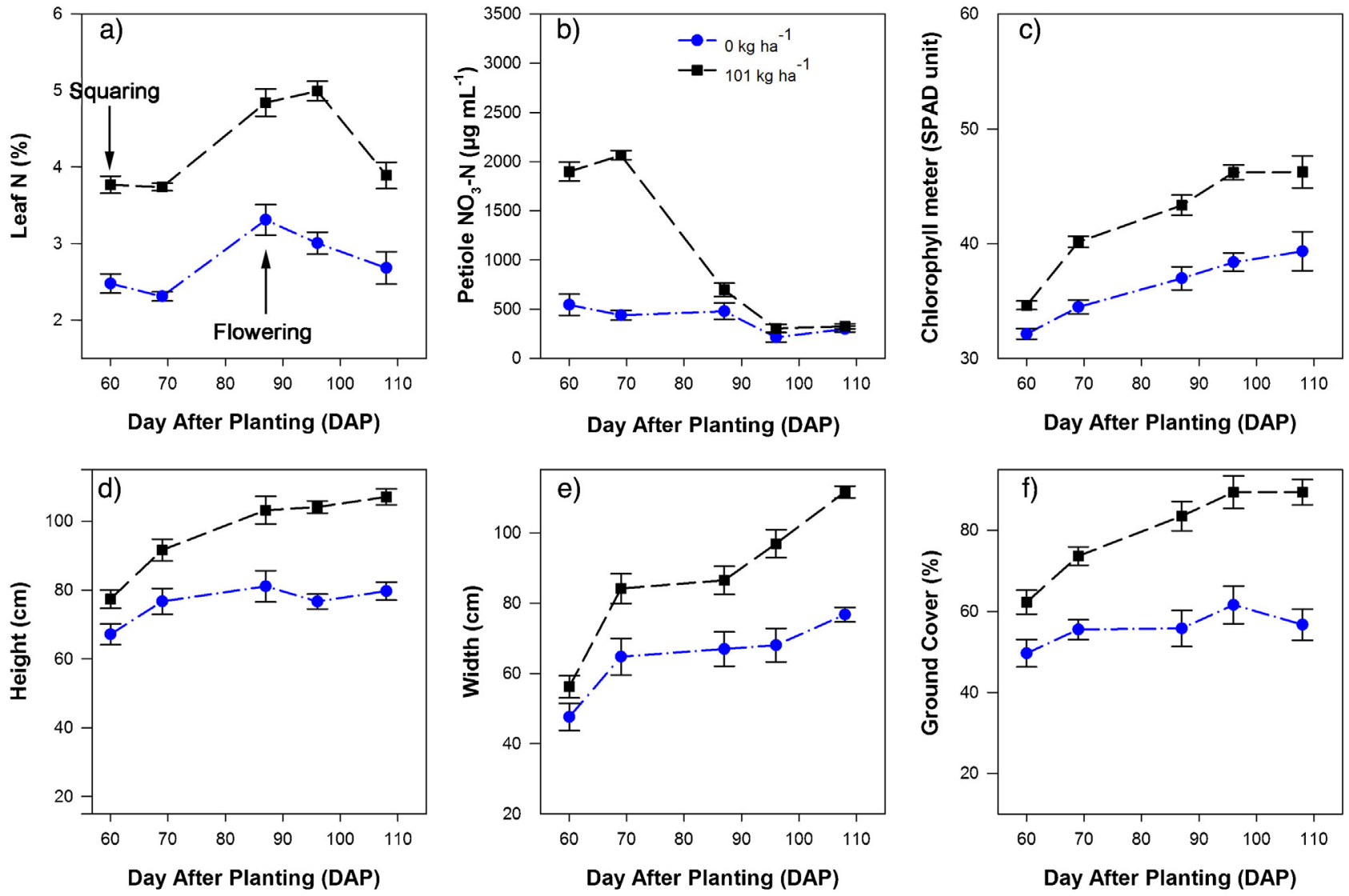

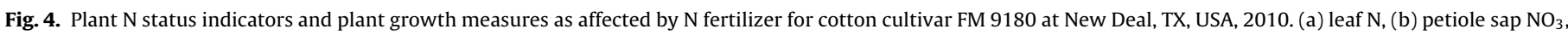
(c) SPAD readings, (d) plant height, (e) canopy width, and (f) percent ground cover. 

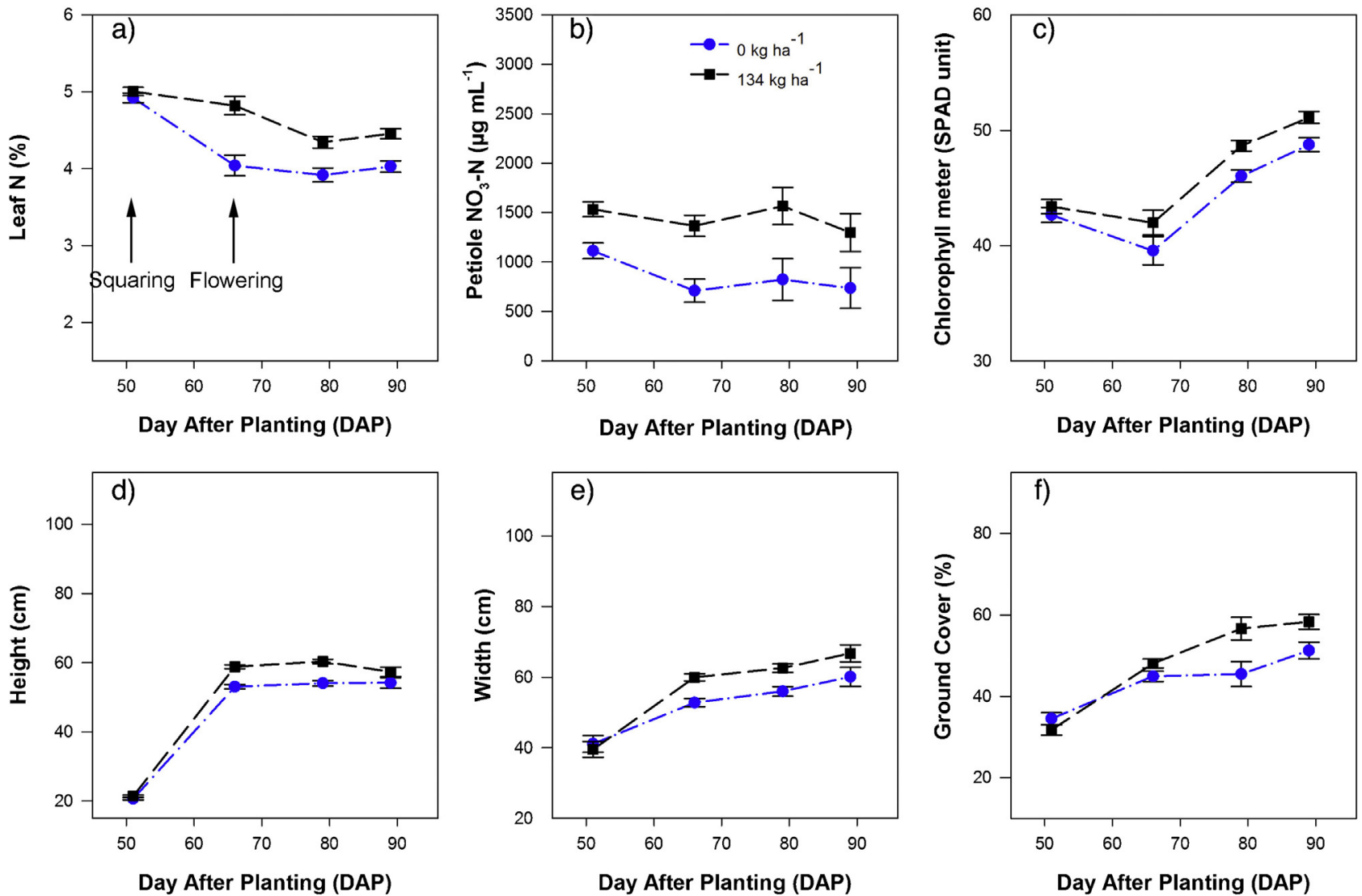

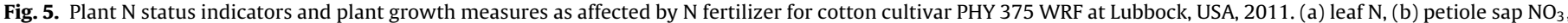
(c) SPAD readings, (d) plant height, (e) canopy width, and (f) percent ground cover.
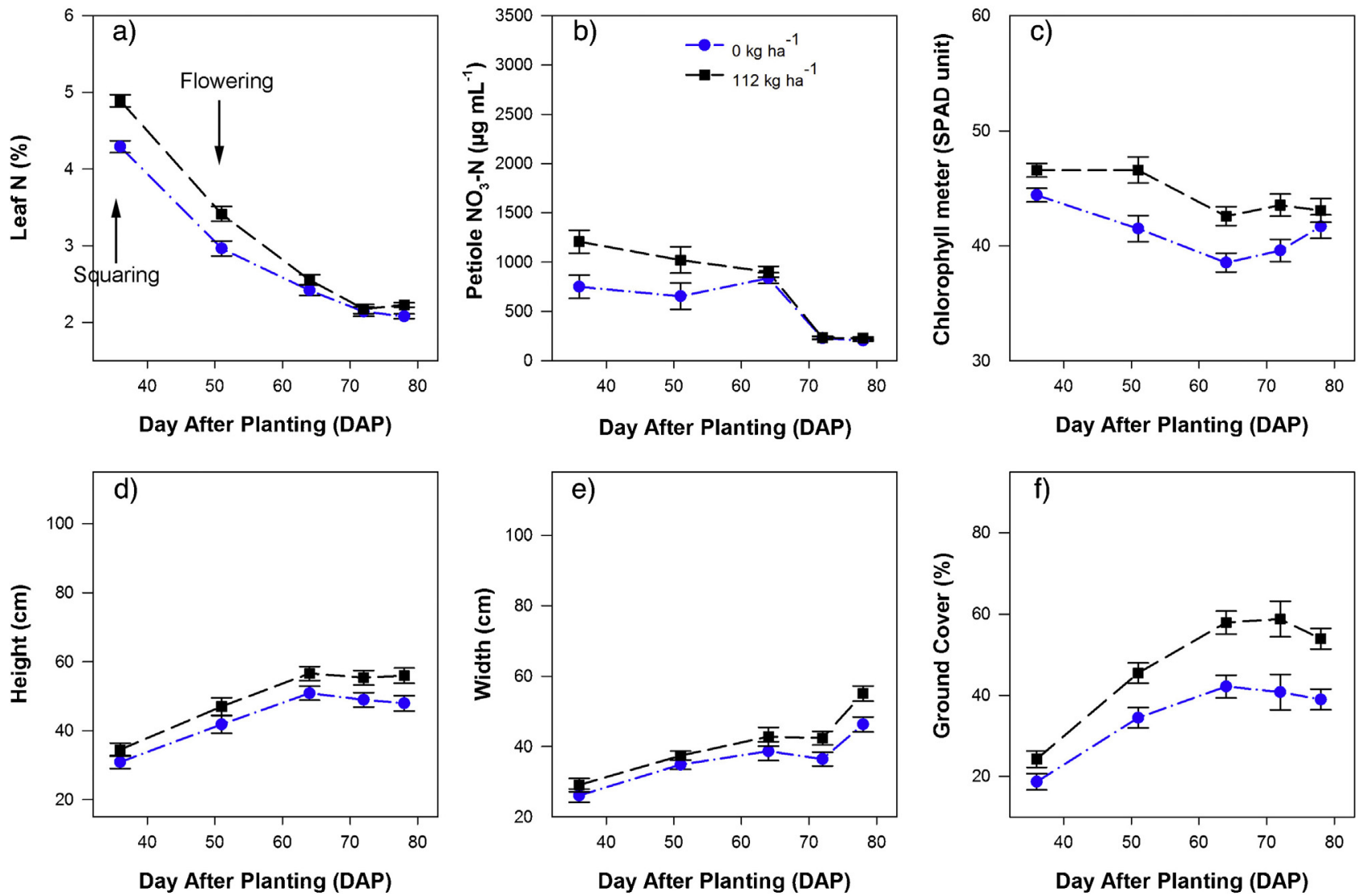

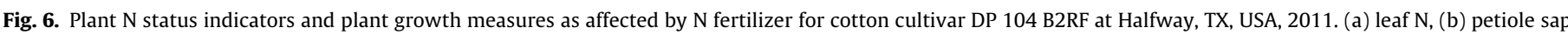
$\mathrm{NO}_{3}$, (c) SPAD readings, (d) plant height, (e) canopy width, and (f) percent ground cover. 
of cultivar effects on the plant $\mathrm{N}$ indicators. Our best comparison is at New Deal in 2010. There it is noted that the SPAD meter readings for ST5458 were greater than for FM 9180, and the plant heights values were the opposite. Plant heights at all sites leveled off during flowering, and leaf declined as $\mathrm{N}$ is mobilized to the seed. We did not assess boll number or final lint or seed yield in this study. In practice boll load (i.e. number and size) is an important plant parameter that impacts $\mathrm{N}$ and water requirements, but it is not as easily and rapidly assessed as plant height, plant width and ground cover.

\section{Conclusions}

Nitrogen fertilizer response was similar among the plant $\mathrm{N}$ indicators leaf $\mathrm{N}$, petiole- $\mathrm{NO}_{3}$ and SPAD readings. Response to $\mathrm{N}$ in plant $\mathrm{N}$ indicators and plant parameters was greatest in the wet 2010 season compared to the dry 2011 season. Plant height and petiole $\mathrm{NO}_{3}$ was markedly lower in the 2011 drought season. Pooled across the entire growing seasons, leaf $\mathrm{N}$ and SPAD readings both had high positive correlation with plant parameters. The exception was the strong negative correlation between leaf $\mathrm{N}$, petiole- $\mathrm{NO}_{3}$ and all plant measures in Halfway in 2011. In that site-year, plant height and crop width were low due to drought, and the absence of an $\mathrm{N}$ fertilizer effect meant that low petiole $\mathrm{NO}_{3}$ was not a useful measure. Low readings of petiole $\mathrm{NO}_{3}$ in many cases would preclude use of that measure for late-season $\mathrm{N}$ management. In conclusion, information on plant measures such as height and cover and width are valuable data to be considered on concentration-based plant $\mathrm{N}$ status indicators.

\section{References}

Bondada, B.R., Oosterhuis, D.M., Norman, R.J., Baker, W.H., 1996. Canopy photosynthesis, growth, yield, and boll ${ }^{15} \mathrm{~N}$ accumulation under nitrogen stress in cotton. Crop Sci. 36, 127-133.

Boquet, D.J., Moser, E.B., Breitenbeck, G.A., 1994. Boll weight and within-plant yield distribution in field-grown cotton given different levels of nitrogen. Agron. J. 86, 20-26.

Bronson, K.F., Booker, J.D., Keeling, J.W., Boman, R.K., Wheeler, T.A., Lascano, R.J., Nichols, R.L., 2005. Cotton canopy reflectance at landscape scale as affected by nitrogen fertilization. Agron. J. 98, 579-587.

Bronson, K.F., Chua, T.T., Booker, J.D., Keeling, J.W., Lascano, R.J., 2003. In-season nitrogen status sensing in irrigated cotton. II. Leaf nitrogen and biomass. Soil Sci. Soc. Am. J. 67, 1439-1448.

Bronson, K.F., Malapati, A., Scharf, P.C., Nichols, R.L., 2011. Canopy reflectance-based nitrogen management strategies for subsurface drip Irrigated cotton in the Texas High Plains. Agron. J. 103, 422-430.

Bronson, K.F., Onken, A.B., Keeling, J.W., Booker, J.D., Torbert, H.A., 2001. Nitrogen response in cotton as affected by tillage system and irrigation level. Soil Sci. Soc. Am. J. 65, 1153-1163.

Burke, J.J., Wanjura, D.F., 2010. Plant responses to temperature extreme. In: Stewart, J.M., Oosterhuis, D.M., Heitholt, J.J., Mauney, J.R. (Eds.), Physiology of Cotton. Springer Publishing Co., New York, NY.

Buscaglia, H.J., Varco, J.J., 2002. Early detection of cotton leaf nitrogen status using leaf reflectance. J. Plant Nutr. 25, 2067-2080.

Colwell, J.E., 1974. Vegetation canopy reflectance. Remote Sens. Environ. 3, $175-183$.

Fernandez, C.J., Cothern, J.T., McInness, K.J., 1996. Partitioning of biomass in water-and nitrogen-stressed cotton during pre-bloom stage. J. Plant Nutr. 19, 595-617.

Freeman, K., Girma, K., Arnall, D.B., Mullen, R.W., Martin, K.L., Teal, R.K., Raun, W.R., 2007. By-plant prediction of corn forage biomass and nitrogen uptake at various growth stages using remote sensing and plant height. Agron. J. 99, 530-536.

Gardner, B.R., Tucker, T.L., 1967. Nitrogen effects on cotton: I. Vegetative and fruiting characteristics. Soil Sci. Soc. Am. Proc. 31, 780-785.

Gerik, T.J., Oosterhuis, D.M., Torbert, H.A., 1998. Managing cotton nitrogen supply. Adv. Agron. 64, 115-147.

Grundon, N.J., 1987. Hungry Crops: A Guide to Mineral Deficiency in Field Crops. Queensland Department of Primary Industries, Brisbane, Australia.

Hay, R., Porter, J., 2006. The Physiology of Crop Yield. Blackwell Publishing, Oxford, pp. 109.

Huete, A.R., Jackson, R.D., Post, D.F., 1985. Spectral response of a plant canopy with different soil backgrounds. Remote Sens. Environ. 17, 37-53.

Jackson, B.S., Gerik, T.J., 1990. Boll shedding and boll load in nitrogen-stressed cotton. Agron. J. 82, 483-488.
Jackson, R.D., Reginato, R.J., Pinter Jr., P.J., Idso, S.B., 1979. Plant canopy information extraction from composite scene reflectance of row crops. Appl. Opt. 18 3775-3782.

Jones, C.L., Maness, N.O., Stone, M.L., Jayasekara, R., 2007. Chlorophyll estimation using multi-spectral reflectance and height sensing. Trans. ASABE 50, 1867-1872.

Lascano, R.J., Salisbury, D.R., 1993. MacPET: software to calculate potential evapotranspiration. In: MP-1752. Texas Agric. Exp. Stn.

Liu, K., Wiatrak, P., 2011. Corn (Zea mays L.) plant characteristics and grain yield response to $\mathrm{N}$ fertilization programs in no-tillage system. Am. J. Agric. Biol. Sci. 6, 172-179.

Maas, S.J., 1997. Structure and reflectance of irrigated cotton leaf canopies. Agron. J 89, 54-59.

Maas, S.J., 1998. Estimating cotton canopy ground cover from remotely sensed scene reflectance. Agron. J. 90, 384-388.

Malavolta, E., Nogueira, N.G.L., Heinrichs, R., Higashi, E.N., Rodríguez, V., Guerra E., de Oliveira, S.C., Cabral, C.P., 2004. Evaluation of nutritional status of the cotton plant with respect to nitrogen. Commun. Soil Sci. Plant Anal. 35, 1007-1019

Martinez, D.E., Guiamet, J.J., 2004. Distortion of the SPAD 502 chlorophyll meter readings by changes in irradiance and leaf water status. Agronomie 24, 41-46.

Mateos, L., Berengena, J., Orgaz, F., Diz, J., Fereres, E., 1991. A comparison between drip and furrow irrigation in cotton at two levels of water supply. Agric. Water Manage., 19 313-19324.

Milroy, S.P., Bange, M.P., Sadras, V.O., 2001. Profiles of leaf nitrogen and light in reproductive canopies of cotton (Gossypium hirsutum). Ann. Bot. 87 325-333.

Osborne, S.L., Schepers, J.S., Francis, D.D., Schlemmer, M.R., 2002. Detection of phosphorus and nitrogen deficiencies in corn using spectral radiance measurements. Agron. J. 94, 1215-1221.

Oosterhuis, D.M., 2001. Physiology and nutrition of high yielding cotton in the USA Informações Agronômicas Piracicaba 95, 18-24.

Peterson, T.A., Blackmer, T.M., Francis, D.D., Schepers, J.S., 1993. Using a SPAD to Improve N management. Historical Materials from University of NebraskaLincoln Extension. University of Nebraska-Lincoln Extension, 〈http:/ digitalcommons.unl.edu/cgi/viewcontent.cgi?article=2349\&context= extensionhist $\rangle$ (verified December 16, 2013).

Radin, J.W., Mauney, J.R., 1986. The Nitrogen Stress Syndrome. Cotton Physiology. The Cotton Foundation, Memphis, TN, pp. 91-105.

Ramey, H.H., 1986. Stress influences on fiber development. In: Mauney, J.R., Stewart, J.McD. (Eds.), Cotton Physiology. The Cotton Foundation, Memphis, TN, pp. 351-359.

Read, J.J., Tarpley, L.M., McKinion, J.M., Reddy, K.R., 2002. Narrow-waveband reflectance ratios for remote estimation of nitrogen status in cotton. J. Environ. Qual. 31, 1436-1452.

Ritchie, G.L., Sullivan, D.G., Vencill, W.K., Bednarz, C.W., Hook, J.E., 2010. Sensitivities of normalized difference vegetation index and a green/red ratio index to cotton ground cover fraction. Crop Sci. 50, 1000-1010.

Rosolem, C.A., Van Meliss, V., 2010. Monitoring nitrogen nutrition in cotton. Rev. Bras. Cienc. Solo 34, 1601-1607.

Sabbe, W.E., Hodges, S.C., 2010. Interpretation of plant mineral status. In: Stewart, J.M., Oosterhuis, D.M., Heitholt, J.J., Mauney, J.R. (Eds.), Physiology of Cotton. Springer Publishing Co., New York, NY.

Sabbe, W.E., Zelinski, L.J., 1990. Plant analysis as an aid in fertilizing cotton. In: Westerman, R.L. (Ed.), Soil Testing and Plant Analysis. , third ed. Soil Science Society of America, Inc., Madison, WI.

SAS Institute Inc., 2013. The SAS System for Windows Version 9.3. SAS Institute Inc. Cary, NC.

Shaver, T., Khosla, R., Westfall, D., 2011. Evaluation of two crop canopy sensors for nitrogen variability determination in irrigated maize. Precis. Agric. 12, $892-905$.

Silvertooth, J.C., Bronson, K.F., Norton, E.R., Mikkelsen, R., 2011. Nitrogen utilization by Western U.S. cotton. Better Crops Plant Food 95, $21-23$.

Stewart, J.McD., 1986. Integrated events in the flower and fruit. In: Mauney, J.R., Stewart, J.McD. (Eds.), Cotton Physiology. Cotton Foundation, Memphis, TN, pp. 261-297.

Stewart, J.M., Oosterhuis, D.M., Heitholt, J.J., Mauney, J.R. (Eds.), 2010. Cotton Physiology. Springer Publishing Co., New York, NY.

Sui, R., Thomasson, J.A., 2006. Ground-based sensing system for cotton nitrogen status determination. Trans. ASABE 49, 1983-1991.

Takebe, M., Yoneyama, T., Inada, K., Mukarami, T., 1990. Spectral reflectance ratio of rice canopy for estimating crop nitrogen status. Plant Soil 122, 295 297.

Thenkabail, P.S., Smith, R.B., De Pauw, E., 2000. Hyperspectral vegetation indices and their relationships with agricultural crop characteristics. Remote Sens. Environ. 71, 158-182.

Verstraete, M.M., Pinty, B., 1991. The potential contribution of satellite remote sensing to the understanding of arid lands processes. Vegetation 91, 59-72.

Wiedenfeld, B., Wallace, B.W., Hons, F., 2009. Indicators of cotton nitrogen status. J. Plant Nutr. 32, 1353-1370.

Wood, C.W., Tracy, P.W., Reeves, D.W., Edmisten, K.L., 1992. Determination of cotton nitrogen status with a hand-held chlorophyll meter. J. Plant Nutr. 15, 1435-1448. 
Yabaji, R., Nusz, J.W., Bronson, K.F., Malapati, A., Booker, J.D., Nichols, R.L., Thompson, T.L., 2009. Nitrogen management for subsurface drip irrigated cotton: Ammonium thiosufalte, timing, and canopy reflectance. Soil Sci. Soc. Am. J. 73, 589-597.

Yoder, B., Pettigrew-Crosby, R., 1995. Predicting nitrogen and chlorophyll content and concentrations from reflectance spectra $(400-2500 \mathrm{~nm})$ at leaf and canopy scales. Remote Sens. Environ. 53, 199-211.
Zelinski, L.J., 1996. Interaction of Water and Nitrogen Stress on the Growth and Development of Cotton. University of California, Davis, CA, Ph.D. Dissertation. Zhao, D., Reddy, K.R., Kakani, V.G., Read, J.J., 2010. Remote-sensing algorithms for estimating nitrogen uptake and nitrogen-use efficiency in cotton. Acta Agric. Scand. Sect B 60, 500-509.

Zhao, D., Reddy, K.R., Kakani, V.G., Read, J.J., Koti, S., 2007. Canopy reflectance in cotton for growth assessment and lint yield prediction. Eur. J. Agron. 26, 335-344. 